\title{
The PI3K inhibitor LY294002 prevents p53 induction by DNA damage and attenuates chemotherapy-induced apoptosis
}

\author{
J Bar $^{1,2}$, N Lukaschuk ${ }^{2}$, A Zalcenstein ${ }^{2}$, S Wilder ${ }^{2}$, R Seger ${ }^{3}$ and \\ M Oren ${ }^{\star 2}$ \\ 1 The Chaim Sheba Medical Center, Department of Oncology, Tel Hashomer, \\ Israel \\ 2 Department of Molecular Cell Biology, Weizmann Institute of Science, \\ Rehovot, Israel \\ ${ }^{3}$ Department of Biological Regulation, Weizmann Institute of Science, Rehovot, \\ Israel \\ * Corresponding author: M Oren, POB 26, Rehovot 76100, Israel. \\ Tel: + 9728 9342358; fax: 9728 9346004; \\ E-mail: moshe.oren@weizmann.ac.il
}

Received 02.11.04; revised 15.4.05; accepted 28.4.05; published online 03.6.05 Edited by G Melino

\section{Abstract \\ The $\mathrm{p} 53$ tumor suppressor plays a key role in the natural protection against cancer. Activation of p53 by DNA- damaging agents can contribute to successful elimination of cancer cells via chemotherapy-induced apoptosis. The phosphatidylinositol-3 kinase (PI3K) pathway, triggered in normal cells upon exposure to growth factors, regulates a cascade of proliferation and survival signals. The PI3K pathway is abnormally active in many cancers, thus making it an attractive target for inactivation in an attempt to achieve better cancer therapy. We report here that exposure to LY294002, a potent PI3K inhibitor, aborts the activation of p53 by several drugs commonly used in cancer chemotherapy. Concomitantly, LY294002 attenuates p53-dependent, chemo- therapy-induced apoptosis of cancer cells. These findings invoke an unexpected positive role for PI3K in p53 activation by anticancer agents, and suggest that the efficacy of PI3K inhibitors in cancer therapy may be greatly affected by the tumor p53 status. \\ Cell Death and Differentiation (2005) 12, 1578-1587. \\ doi:10.1038/sj.cdd.4401677; published online 3 June 2005}

Keywords: PI3K; p53; apoptosis; LY294002; 5-fluorouracil

\footnotetext{
Abbreviations: ARF, alternative reading frame; ATM, Ataxiatelangiectasia-mutated kinase; ATR, ATM and Rad3-related kinase; CisPt, cisplatin; ERK, extracellular regulated kinase; CPT, camptothecin; FCS, fetal calf serum; 5FU, 5-fluorouracil; MEF, mouse embryonic fibroblasts; HI, heat inactivated; PAGE, polyacrylamide gel electrophoresis; PDK, PI3K-dependent kinase; PI3K, phosphatidylinositol 3-kinase; wt, wild type; PI, propidium iodide
}

\section{Introduction}

The p53 protein is a sequence-specific transcription factor that functions as a major tumor suppressor in mammals. This role is highlighted by the abrogation of normal p53 function in the majority of human cancers. ${ }^{1-3}$ Animal knockout models reveal markedly increased cancer incidence in the absence of p53. ${ }^{4,5}$ Most cases of Li-Fraumeni syndrome, a human inherited predisposition for cancer, are due to germline mutations in the p53 locus. ${ }^{6,7}$ p53 can respond to potentially carcinogenic insults by inducing extensive phenotypic alterations, most notably, growth arrest, replicative senescence, or apoptotic elimination of the damaged cell, thus preventing the propagation of cancer-prone cells. In nonstressed cells, p53 levels are typically very low, owing to the rapid degradation of the protein by the ubiquitin-proteasome pathway, a process greatly stimulated by the oncogenic E3 ubiquitin ligase Mdm2.8,9 Exposure to DNA-damaging agents can lead to extensive induction and activation of $\mathrm{p} 53$, primarily through post-translational modifications of the protein that block its degradation and increase its biochemical potency. The upregulation of p53 following DNA damage is of paramount importance to its role as a tumor suppressor, and is also believed to contribute to efficient cell killing by anticancer agents. $^{10,11}$

Class I phosphatidylinositol 3-kinase (PI3K) and its downstream effectors have emerged in recent years as a prominent proliferation- and survival-related pathway. PI3K is a heterodimer, consisting of a catalytic and a regulatory subunit, which form an inactive complex in the cytoplasm of resting cells. In response to receptor tyrosine kinase activation, PI3K is recruited to the plasma membrane and becomes active. Its primary in vivo product, phosphatidylinositol $(3,4,5) \mathrm{P} 3$, recruits pleckstrin-homology $(\mathrm{PH})$ domain-containing proteins to the plasma membrane, thus activating them.

The PI3K pathway is often deregulated in human cancer. Activating mutations and gene amplification in both subunits of class IA PI3K have been found in various human malignancies, qualifying $\mathrm{PI} K \mathrm{~K}$ as a potential oncogene. ${ }^{12-15}$ The available knowledge about PI3K suggests that attenuation of survival signals emanating downstream to it can be instrumental in bringing about cancer cell death. ${ }^{12,16,17}$ This marks PI3K as a potential target for novel cancer treatments, aimed at its inhibition.

We now report that induction of $\mathrm{p} 53$ by Cisplatin (CisPt) in cultured cells requires the presence of serum factors. Moreover, p53 induction is blocked by the PI3K inhibitor LY294002, implicating the PI3K pathway as the critical mediator of the positive role of serum factors in p53 activation. LY294002 inhibits p53 stabilization and functional activation in a variety of cell types and in response to several different DNAdamaging agents, and attenuates the ensuing p53-dependent killing of cancer cells. Hence, the p53 status of the targeted 
tumors may be an important determinant in the implementation of $\mathrm{PI} 3 \mathrm{~K}$ inhibitors for cancer treatment.

\section{Results}

\section{p53 induction by CisPt is dependent on growth factor signaling}

We have previously shown that p53 protein accumulation upon exposure to DNA damage occurs efficiently in sparse cells, but is attenuated when cells are maintained at high culture density. ${ }^{18}$ In an attempt to elucidate the signaling pathways required for p53 induction in sparse cells, we explored the effect of serum on this induction. As shown in Figure 1, exposure of mouse embryo fibroblasts (MEFs) to CisPt in the presence of $5 \%$ fetal calf serum (FCS) led to a marked increase in p53 protein levels (compare lanes 1 and 2). However, p53 induction was far less efficient when cells were exposed to CisPt in the absence of serum (lanes 3,4). Of note, serum depletion was for a total period of only $6 \mathrm{~h}$, which was too short to exert significant effects on cell cycle distribution, as confirmed by the absence of a reduction in the proportion of BrdU-incorporating cells (Supplementary Figure $\mathrm{S} 1)$. This argues against the possibility that the failure to induce p53 is a secondary consequence of a growth arrest imposed by serum deprivation. Rather, these findings suggest that intracellular signal transduction, elicited by serum-derived growth factors, is required for optimal induction of a p53 response by $\mathrm{CisPt}$. Of note, inclusion of the proteasome inhibitor MG132 in the culture medium, which is expected to prevent p53 degradation, abrogated completely the serumdependent differences in p53 protein levels (lanes 5-8). This implies that the differences in p53 levels seen in the absence of MG132 are not due to different rates of p53 synthesis, but rather to differences in p53 stabilization. Thus, whereas stabilization of p53 following CisPt treatment occurs efficiently in the presence of serum, it fails to occur when serum is withdrawn. It is also noteworthy that the experiment in Figure 1 employed alternative reading frame (ARF)-null MEFs, imply-

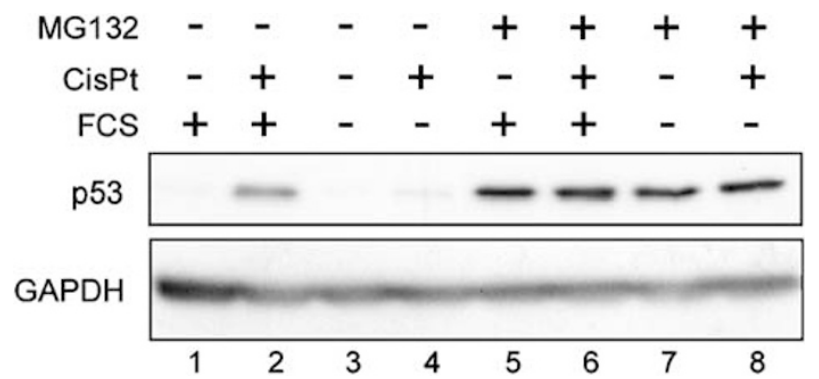

Figure 1 Serum-derived factors modulate the $\mathrm{p} 53$ response to CisPt. ARF-null, p53 $+1+$ MEFs were plated at a density of 200000 cells per $6 \mathrm{~cm}$ dish. After $18 \mathrm{~h}$, the serum was washed off, and cells were incubated with or without $5 \%$ FCS. After $1 \mathrm{~h}, \mathrm{MG} 132(25 \mu \mathrm{M})$ was added, and the cells were either treated or not treated with CisPt $(16 \mu \mathrm{g} / \mathrm{ml})$, as indicated, for an additional $5 \mathrm{~h}$. Cell extracts were subjected to SDS-polyacrylamide gel electrophoresis (PAGE), followed by Western blot analysis with the CM5 p53-specific antibody. GAPDH was used as a loading control ing that the effect of serum on p53 stabilization is independent of the ARF tumor suppressor.

\section{The PI3K inhibitor LY294002 prevents induction of p53 by DNA damage}

To explore the contribution of particular signal transduction cascades to the effect of serum growth factors on p53 induction, cells were exposed to CisPt in the presence of specific chemical inhibitors. The raf-MEK-ERK (extracellularregulated kinase) pathway, which is potently induced by a variety of growth factors, has been implicated both in the response to DNA damage ${ }^{19}$ and in the subsequent induction of p53. ${ }^{20}$ PD98059, a specific inhibitor of mitogen-activated/ extracellular-regulated kinase 1 (MEK1), ${ }^{21}$ reduced the phosphorylation of ERK1 and ERK2 to about 18 and 34\%, respectively, but did not prevent the induction of p53 by CisPt (Figure 2a). High cell density, previously shown to inhibit p53 induction by $\mathrm{CisPt}^{18}{ }^{18}$ mildly attenuated ERK phosphorylation (lanes 3,4). However, a slight decrease in ERK phosphorylation was actually also observed when sparse cells were treated with CisPt, even though these conditions led to strong p53 accumulation (lanes 2,4). This further supports the notion that the raf-MEK-ERK pathway is not involved in the stabilization of p53 in this experimental system.

p38, another member of the mitogen-activated protein kinase (MAPK) superfamily, is only mildly induced by growth factors, but is markedly induced by various stress signals, including $\mathrm{CisPt}^{22}$ p38 phosphorylates p53, ${ }^{23-26}$ and is required for its activation by some types of DNA damage. ${ }^{27}$ However, whereas the p38 inhibitor SB203580 ${ }^{28}$ completely blocked the phosphorylation of MAPKAPK-2 on threonine 334 , a validated p38 target, $^{29}$ it had only a minimal impact of p53 induction by CisPt treatment (Figure 2b). Similar results were obtained with another p38 inhibitor, SB202190 (data not shown), indicating that p38 activity is not required for p53 stabilization in CisPt-treated cells.

Another important signal transduction pathway that is activated by a variety of growth factors is the PI3K pathway. Of note, phosphorylation of AKT on serine 473, a PI3Kdependent target of the PDK2 kinase, was significantly higher in CisPt-treated sparse cultures than in their dense counterparts (Figure 2c, lanes 3,4), concomitant with the more efficient p53 induction. To assess the possible role of PI3K signaling in facilitating p53 induction by DNA damage, cells were exposed to $\mathrm{CisPt}$ in the absence or presence of the PI3K inhibitor LY294002, ${ }^{30}$ As seen in Figure 2c, LY294002 abrogated almost completely the induction of $\mathrm{p} 53$ by $\mathrm{CisPt}$ (compare lanes 4,8); in fact, the slight p53 induction that was still observable correlated well with the residual amount of PI3K activity retained under those conditions, as measured by AKT phosphorylation. Induction of p53 by CisPt was also markedly attenuated by Wortmannin, another PI3K inhibitor (data not shown). Hence, CisPt-induced p53 accumulation is effectively blocked by PI3K inhibitors.

The experiments described above were performed in ARFnull MEFs; these cells do not undergo replicative senescence in culture, thus reducing experiment-to-experiment variation due to differential activation of p53 by DNA damage in cells 
a

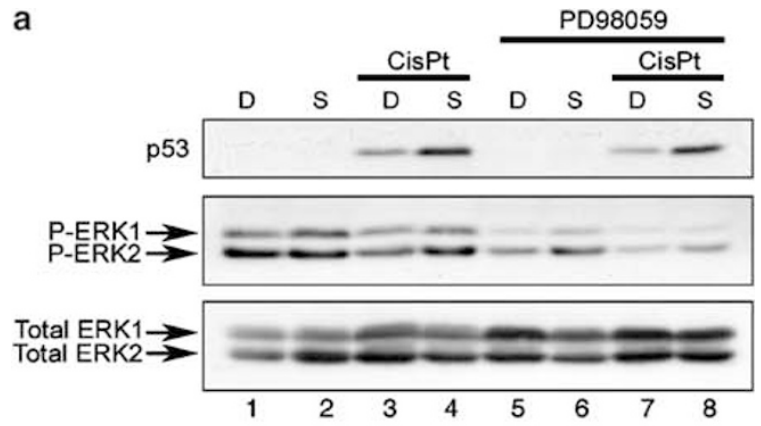

b

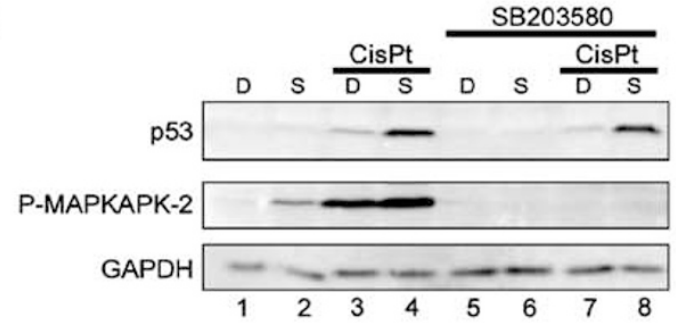

c

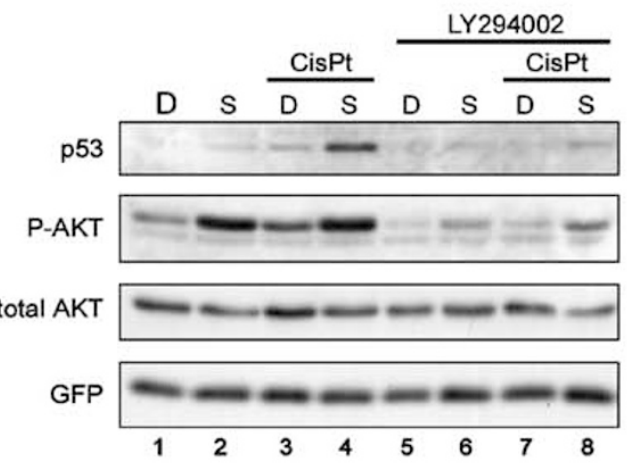

d

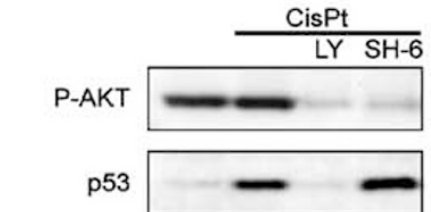

total AKT

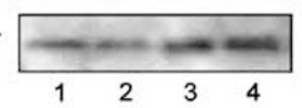

e

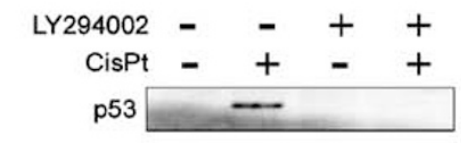

Phos-Ser $18 \longrightarrow$

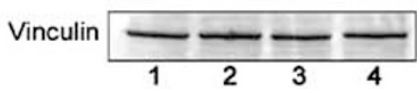

f

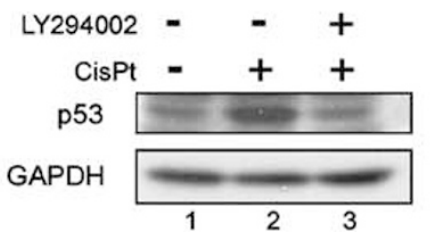

that are approaching senescence. ${ }^{18}$ However, a similar inhibition of CisPt-induced p53 induction in the presence of LY294002 was also seen in wild-type (wt) MEFs (Supplementary Figure S2).

One of the most important targets of PI3K is the AKT/PKB kinase. The relationship between AKT and p53 is rather complex: on the one hand, AKT phosphorylates Mdm2 and presumably increases its nuclear activity, thereby augmenting p53 degradation..$^{31,32}$ On the other hand, PI3K regulates the levels of p21 $1^{\text {Waf1 } 1}$ in a p53-dependent manner, and this effect is blocked by dominant negative AKT, suggesting that PI3K and AKT increase the activation of p21 ${ }^{\text {Wat1 }}$ by $p 53 .^{33,34}$ The role of AKT in p53 activation by CisPt was, therefore, tested by applying $\mathrm{SH}-6$, a phosphatidyl-inositol analog that inhibits AKT activation. ${ }^{35}$ As expected, $\mathrm{SH}-6$ indeed abrogated AKT phosphorylation, but did not affect at all p53 stabilization following CisPt treatment (Figure 2d, lanes 2,4). This was unlike the effect of LY294002, which efficiently inhibited both processes (lanes 2,3). Thus, AKT activity is not involved in p53 induction by CisPt under the experimental conditions employed in this study.

Although LY294002 is widely used as a PI3K inhibitor, it can also inhibit to varying degrees other members of the PI3K family, including DNA-dependent protein kinase (DNA-PK), ataxia-telangiectasia-mutated kinase (ATM), and ATM and Rad3-related kinase (ATR) ${ }^{36-39}$ ATM and ATR are of particular relevance, because both are involved in p53 activation in response to DNA damage, ${ }^{40,41}$ and ATR activation by CisPt has specifically been shown to mediate p53 phosphorylation on serine 15, a direct target of this kinase. ${ }^{41-43}$ Hence, although complete inactivation of

Figure 2 Inhibition of PI3K, but not of MEK, p38, or AKT, prevents p53 induction by DNA damage without affecting p53 serine 15 phosphorylation. (a) ARF-null MEFs were plated under dense (D) or sparse (S) culture conditions, as described under Materials and Methods. PD98059 $(30 \mu \mathrm{M})$ was added $22 \mathrm{~h}$ later, followed $1 \mathrm{~h}$ later by CisPt ( $16 \mu \mathrm{g} / \mathrm{ml})$ as indicated. After 5 additional hours, cells were harvested and proteins analyzed as in Figure 1, using antibodies directed against p53 (CM5), Phospho-ERK (P-ERK), or total ERK, used as a loading control. (b) ARF-null MEFs were plated as in (a). SB203580 $(20 \mu \mathrm{M})$ was added $21 \mathrm{~h}$ later, followed $1 \mathrm{~h}$ later by CisPt $(16 \mu \mathrm{g} / \mathrm{ml})$ as indicated. After 4 additional hours, cells were harvested and analyzed as in Figure 1, using antibodies directed against p53 (CM5), Phospho-MAPKAP2 as an indicator of p38 activity, or GAPDH as a loading control. (c) ARF-null MEFs, infected with a recombinant retrovirus encoding GFP (see Materials and Methods), were plated as in (a) and subjected $20 \mathrm{~h}$ later to treatment with LY294002 $(20 \mu \mathrm{M})$, followed $1 \mathrm{~h}$ later by CisPt $(16 \mu \mathrm{g} / \mathrm{ml})$ as indicated. After 4 additional hours, cells were harvested and analyzed as in Figure 1a, using antibodies against p53 (PAb248 and PAb421), phospho-AKT (P-AKT), total AKT, or GFP as a loading control. (d) ARF-null MEFs were plated in 24-well dishes (70000 cells/well). After $18 \mathrm{~h}$, LY294002 $(20 \mu \mathrm{M}), \mathrm{SH}-6(40 \mu \mathrm{M})$, or DMSO were added. After $80 \mathrm{~min}$, CisPt $(16 \mu \mathrm{g} / \mathrm{ml})$ was added as indicated and cells were harvested after an additional $4.5 \mathrm{~h}$. p53, phospho-AKT (P-AKT) and total AKT were monitored as in (c). (e) ARF-null MEFs were plated as in (a), and $21 \mathrm{~h}$ later, treated with LY294002 (20 $\mu \mathrm{M})$. CisPt $(16 \mu \mathrm{g} / \mathrm{ml})$ was added $1 \mathrm{~h}$ later. Cells were harvested after 4 additional hours, and subjected to analysis as in (a), using antibodies against p53 (PAb248 and PAb421), rabbit polyclonal serum against human $\mathrm{p} 53$ phosphorylated on serine 15 , which recognizes also mouse p53 phosphorylated on serine 18 (Phos-Ser 18 ), or vinculin as a loading control. (f) MEFs derived from SCID mice were plated ( 150000 cells per $6 \mathrm{~cm}$ plate); the next day, they were either treated by LY294002 $(20 \mu \mathrm{M})$ or DMSO control, and $2 \mathrm{~h}$ later, CisPt was added $(16 \mu \mathrm{g} / \mathrm{ml})$. After $5 \mathrm{~h}$, cells were harvested, equivalent amounts of protein were run on SDSPAGE, and Westerm blot was performed for p53 (PAb248 and PAb 421), and for GAPDH as a loading control 
ATM and ATR typically requires higher concentrations of LY294002 than are used in the present study, ${ }^{36,39}$ it was nevertheless important to confirm that the inhibition of p53 accumulation by LY294002 was not due to the extinction of ATM/ART activity. To that end, we monitored the extent of phosphorylation of mouse p53 serine 18 (equivalent to human $\mathrm{p} 53$ serine 15), which is directly targeted by ATM/ATR in response to various types of DNA damage. ${ }^{40-}$ 42 Remarkably, although LY294002 prevented efficiently the induction of $\mathrm{p} 53$ by $\mathrm{CisPt}$ in this experiment, precluding the detection of p53 protein by standard p53-specific antibodies (Figure $2 \mathrm{e}$, lane 4), a prominent increase in serine 18 phosphorylation was nevertheless clearly visible (compare lanes 3,4). This strongly argues that LY294002 does not block ATM/ATR activation under these experimental conditions, nor does it prevent the phosphorylation of p53 by these protein kinases. To determine whether inhibition of DNA-PK by LY294002 may underlie its ability to attenuate p53 induction, we employed MEFs derived from SCID mice, which harbor a mutant, inactive form of DNA-PK catalytic subunit. ${ }^{44}$ As seen in Figure $2 \mathrm{f}$, both the induction of $\mathrm{p} 53$ by $\mathrm{CisPt}$ (compare lanes 1 and 2), and the inhibition of this induction by LY294002 (lane 3) were not affected by the absence of active DNA-PK. Taken together, the data support the conclusion that PI3K itself, rather than PI3K family protein kinases, is the relevant molecular target whose inactivation by LY294002 aborts p53 accumulation, and which is therefore required for this accumulation.

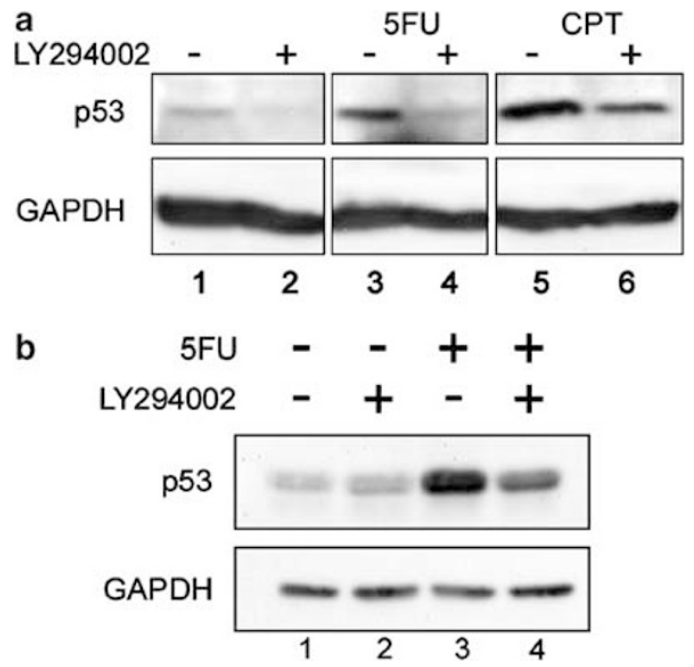

Figure 3 LY294002 inhibits p53 induction in a variety of experimental systems. (a) H5V endothelial cells $(100000)$ were seeded in $3.5 \mathrm{~cm}$ plates. After $20 \mathrm{~h}$ LY294002 $(20 \mu \mathrm{M})$ was added as indicated, followed $2 \mathrm{~h}$ later by $5 \mathrm{FU}(25 \mu \mathrm{g} / \mathrm{ml})$ or CPT $(2 \mu \mathrm{g} / \mathrm{ml})$. Cells were harvested after $5 \mathrm{~h}$ of genotoxic agent treatment, and subjected to analysis as in Figure 1. (b) MCF7 cells $(400000)$ were plated in $6 \mathrm{~cm}$ plates. LY294002 $(20 \mu \mathrm{M})$ was added $17 \mathrm{~h}$ later, followed by $5 \mathrm{FU}(50 \mu \mathrm{g} / \mathrm{ml})$ $1 \mathrm{~h}$ later. Cells were harvested after 5 additional hours, and subjected to analysis as in Figure 1. p53 was visualized with a mixture of PAb1801 and D01. GAPDH was used as a loading control

\section{LY294002 inhibits p53 induction in multiple cell types and in response to multiple DNA-damaging agents}

The effect of LY294002 on p53 induction was next tested in a number of additional experimental conditions. LY294002 treatment of a mouse endothelial cell line $(\mathrm{H} 5 \mathrm{~V})$ reduced basal p53 levels (Figure 3a, lanes 1,2), and inhibited effectively the induction of p53 by 5 -fluoro-uracil $(5 \mathrm{FU}$; lanes $3,4)$; substantial, albeit not complete, attenuation of p53 induction was also observed in cells exposed to the Topoisomerase I inhibitor camptothecin (CPT; lanes 5, 6). The reduction of basal p53 levels might suggest a mechanism that is not strictly dependent on DNA damage in H5V cells; alternatively, these particular cells may be intrinsically exposed to persistent genotoxic stress even under regular tissue culture conditions.

LY294002 also exerted a strong inhibitory effect on p53 induction in MCF7 human breast carcinoma cells treated with 5FU, a drug commonly used for chemotherapy in breast cancer patients (Figure $3 b$ ). In contrast, induction of p53 in MCF7 cells following doxorubicin treatment was not affected by LY294002 (data not shown). Thus, inhibition of PI3K attenuates p53 induction in a variety of different cell types, in response to some, but not all, DNA-damaging chemotherapy agents.

\section{LY294002 inhibits p53-dependent transactivation and apoptosis}

We next examined the effect of LY294002 on the response of human colorectal carcinoma HCT116 cells to 5FU, an agent commonly used to treat colorectal cancer patients. Unlike in the cell types described earlier, LY294002 did not exert a pronounced inhibitory effect on the accumulation of the endogenous wt p53 in 5FU-treated HCT116 cells; in some experiments, LY294002 did not attenuate at all the increase in p53 protein, while in others there was a rather minor decrease in p53 levels relative to cells treated with 5FU alone (Figure 4a, lanes 1-3, and data not shown). The attenuation of p53 induction was more pronounced at higher LY294002 concentrations (Figure 4b, lanes 6-10), although at least some increase in p53 could be observed even at $50 \mu \mathrm{M}$. Interestingly, human p53 serine 15 phosphorylation was not abrogated even in the presence of the highest LY294002 concentrations, again arguing against inhibition of ATM/ATR by LY294002 under these conditions. Despite the rather marginal effect on total p53 protein levels, LY294002 markedly attenuated the increase in p21 ${ }^{\text {Waf1 }}$ protein (Figure $4 a$, lanes 1-3), encoded by a prototypic p53 transcriptional target gene. This increase in p21Waf1 was indeed p53-dependent, and was absent in p53-deficient derivatives of HCT116 cells (lanes 4-6).

To determine whether the inefficient p21 Waf1 protein induction was due to decreased transcriptional activation of the corresponding gene by p53 in the presence of LY294002, real-time reverse transcriptase-polymerase chain reaction (RT-PCR) analysis was performed. As seen in Figure 4c, exposure of HCT116 cells to 5FU led to a three-fold increase in p21 mRNA levels. Remarkably, this increase was greatly 
a
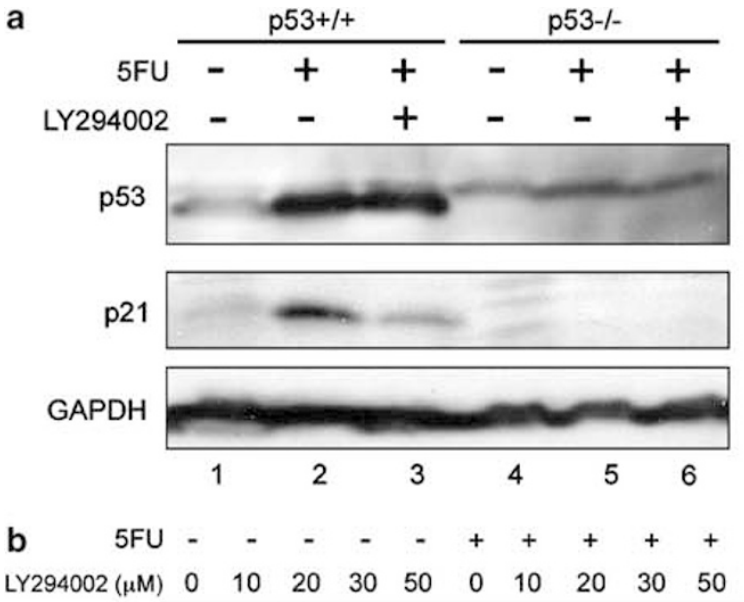

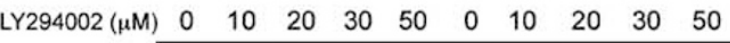

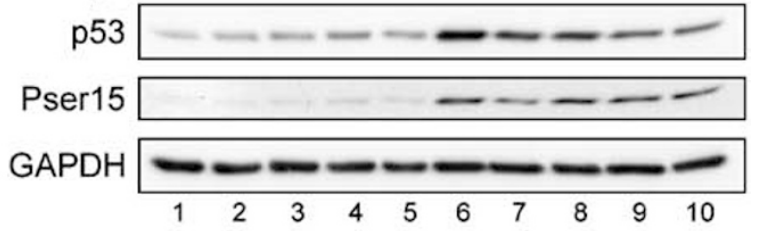

C



d

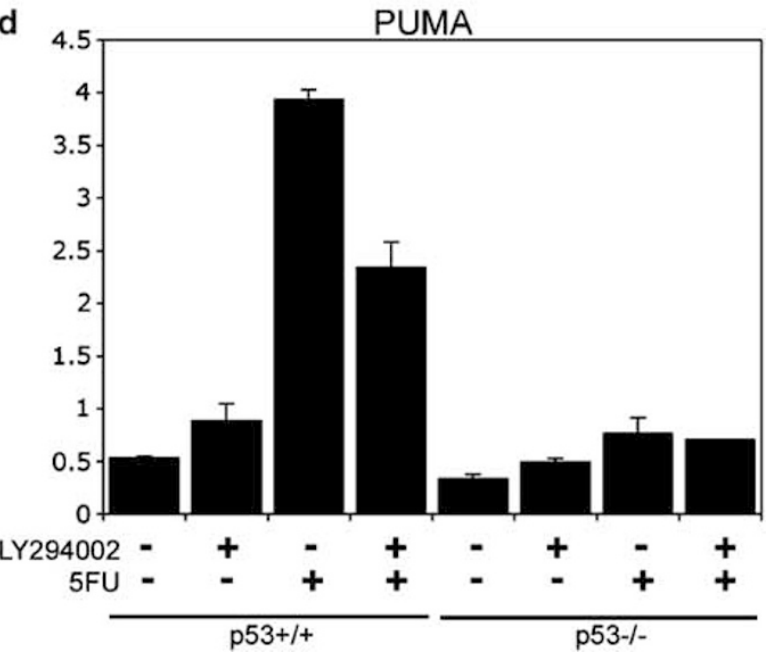

attenuated in the presence of LY294002, confirming that the PI3K inhibitor compromised the potency of p53 as a transcriptional activator. It is noteworthy that this effect was dependent on the presence of wt p53. In p53-deficient HCT116 derivatives, LY294002 actually exerted an opposite effect, mildly augmenting rather than reducing the accumulation of p21 transcripts (Figure 4c). It thus appears that p53independent regulation of p21 gene expression in HCT116 cells may be constitutively repressed by the PI3K pathway, irrespective of the absence or presence of DNA damage.

A similar pattern of regulation also emerged from the analysis of mRNA corresponding to the PUMA gene (Figure 4d), a p53 target that is critical for the induction of p53-dependent apoptosis in stressed cells, ${ }^{45-47}$ as was also the case for another proapoptotic p53 target gene, NOXA (data not shown). Experiments employing a luciferase reporter gene driven by the PUMA promoter, in the absence or presence of p53-specific siRNA, confirmed that the activity of this promoter was largely p53-dependent (Supplementary Figure S3). Moreover, LY294002 partially reduced the activation of this promoter by p53 (Supplementary Figure S3); it is noteworthy that both the stimulatory effect of 5FU and the inhibitory effect of LY294002 were rather mild in this system, most probably due to constitutive p53 activation elicited by transfection-associated stress. In sum, our data imply that despite having a variable and sometimes only marginal effect on overall p53 protein levels in 5FU-treated HCT116 cells, LY294002 exposure exerted a consistent marked inhibitory effect on the biochemical activation of p53 as a transcription factor.

5FU induces HCT116 cell killing, and this death is p53dependent both in vitro and in vivo. ${ }^{48}$ Given the ability of LY294002 to attenuate $\mathrm{p} 53$ activation by $5 \mathrm{FU}$, and particularly the reduced induction of proapoptotic genes such as PUMA and $N O X A$, it was thus important to determine whether the PI3K inhibitor also affected the killing of these colorectal cancer cells by 5FU. As expected, 5FU indeed caused HCT116 cells to undergo apoptosis, as assessed by accumulation of cells with sub-G1 DNA content (Figure 5a). The extent of cell death was substantially lower in p53deficient HCT116 derivatives (Figure $5 \mathrm{c}$ ), confirming that much of the death seen in the p53-positive parental HCT116 cells was p53-dependent. Basal levels of apoptosis in the absence of $5 \mathrm{FU}$ were usually below $5 \%$, did not differ significantly between HCT116 cells with or without Wt p53,

Figure 4 LY294002 inhibits p53-dependent transactivation in HCT116 cells. (a) HCT116 cells ( $553+I+$ ) or their p53-deficient derivatives (p53-I-) were seeded at a density of 300000 cells per $6 \mathrm{~cm}$ dish. After $48 \mathrm{~h}$, LY294002 $(20 \mu \mathrm{M})$ or DMSO was added, followed $2 \mathrm{~h}$ later by $5 \mathrm{FU}(50 \mu \mathrm{g} / \mathrm{ml})$, as indicated. Cells were harvested after $24 \mathrm{~h}$ of $5 \mathrm{FU}$ treatment, and subjected to analysis as in Figure 1, using antibodies against human p53 (a mixture of PAb1801 and D01), p21 ${ }^{\text {WAF1 }}$ (antibody C19), or GAPDH as a loading control. (b) HCT116 cells $(\mathrm{p} 53+/+)$ were seeded $(300000$ cells per $3.5 \mathrm{~cm}$ dish) and treated with the indicated concentrations of LY294002 before addition of 5FU, harvesting and SDS-PAGE as in (a). (c, d) HCT116 cells (p53+/+) or their p53-deficient derivatives (p53-l-) were seeded (700 000 cells per $9 \mathrm{~cm}$ dish), and treated as in (a). After $4.6 \mathrm{~h}$ of $5 \mathrm{FU}$ treatment, cells were harvested, RNA extracted, cDNA prepared, and real-time PCR quantification of p21 (c) and PUMA (d) transcripts was performed as described in Materials and Methods. Results are shown corrected by mRNA levels of $18 \mathrm{~s}$ 

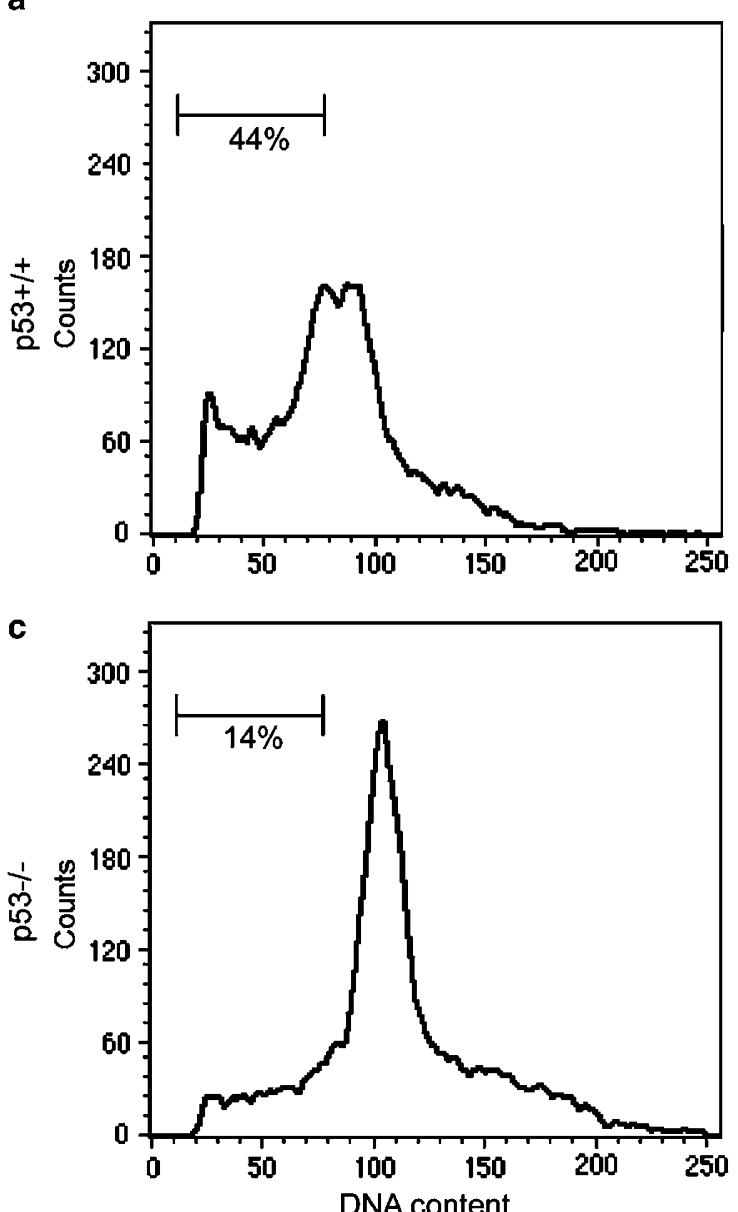
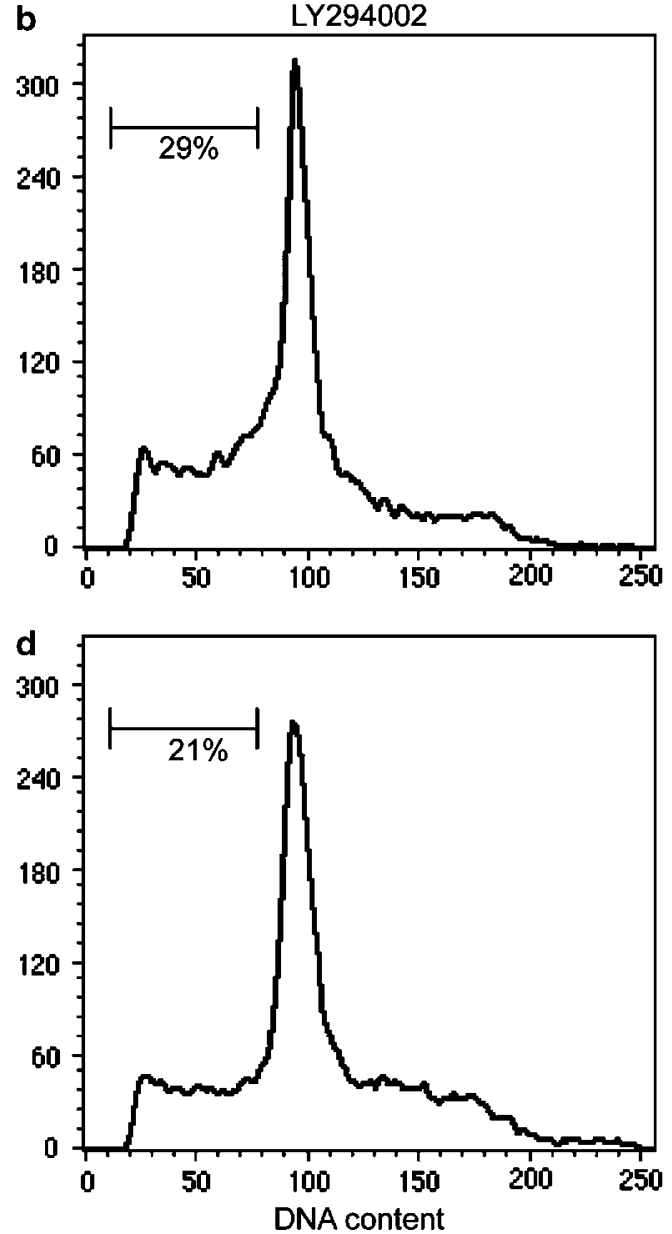



Figure 5 LY294002 protects HCT116 cells from p53-dependent apoptosis. HCT116 cells $(\mathbf{a}, \mathbf{b})$ and their p53-deficient derivatives (c,d) were seeded as in Figure $4 b$. After $48 \mathrm{~h}$, DMSO $(\mathbf{a}, \mathbf{c})$ or LY294002 $(20 \mu \mathrm{M} ; \mathbf{b}$,d) was added. After $2 \mathrm{~h}$ later, $5 \mathrm{FU}(50 \mu \mathrm{g} / \mathrm{ml})$ was added to all cultures. After $48 \mathrm{~h}$ of $5 \mathrm{FU}$ treatment, cells were harvested, fixed, stained with propidium iodide and subjected to FACS analysis. The fraction of cells with sub-G1 DNA content, indicative of apoptosis, is indicated in each panel. (e) Parental HCT116 cells were seeded as in Figure 4b, and treated 2 days later by LY294002 or DMSO control and 5FU at the indicated concentrations, as above. After 2 days, cells were harvested and analyzed for propidium iodide (PI) uptake, as described in Materials and Methods

and were not affected by LY294002 treatment (data not shown). Importantly, LY294002 exposure prior to 5FU treatment resulted in a significant protection from apoptosis (compare Figure $5 a$ to b). The protective effect of LY294002 could also be demonstrated when viability was assessed by propidium iodide $(\mathrm{PI})$ exclusion (Figure 5e). Protection was evident over a wide range of $5 F U$ concentrations, although it was more prominent at lower concentrations of $5 \mathrm{FU}$ (Figure 5e). This pronounced inhibition of apoptosis was seen only in the wt p53-positive cells; in p53-deficient cells, 
LY294002 sometimes actually moderately augmented 5FUinduced apoptosis (compare Figure $5 c$ to $d$ ), whereas in other experiments there was either a mild inhibitory effect or no effect at all (data not shown). Thus, concomitant with its ability to interfere with induction of PUMA and NOXA by 5FU, LY294002 also attenuated the capacity of 5FU to elicit p53dependent apoptosis in HCT116 colorectal cancer cells.

\section{Discussion}

Induction of p53 by genotoxic stress is believed to constitute a major mechanism for prevention of genomic instability, and thereby of cancer initiation and progression. ${ }^{49,50}$ Moreover, this induction can play an important role in mediating the successful killing of wt p53-positive tumor cells by DNAdamaging chemotherapy. ${ }^{10}$ In the present study, we report that the extent of p53 induction by at least some clinically relevant genotoxic agents, as reflected by a net increase in p53 stability as well as in its transcriptional activation potency, is dependent on the availability of growth factors and of signals emanating from their binding to their cognate receptors. Whereas in nontransformed cells, such as MEFs, these signals are likely to be present only when the cells are externally exposed to the proper growth stimuli, such signals are likely to become constitutive in the course of cancer progression. Tumor cells still harboring wt p53 are thus likely, at least in some cases, to undergo a vigorous activation of their endogenous p53 irrespective of external growth stimuli.

We further report that the PI3K inhibitor, LY294002, can efficiently block the induction of p53 by a number of different genotoxic agents. LY294002 can inhibit several members of the PI3K family, including DNA-damage-induced protein kinases such as DNA-PK, ATM, and ATR. In particular, ATM and ATR have been shown to be required for p53 activation by DNA-damaging agents, including CisPt. Although complete inhibition of ATM and ATR typically requires higher concentrations of LY294002 than used in the present study, it was thus necessary to rule out the possibility that one or both of those kinases, rather than PI3K itself, were the primary targets for inhibition by LY294002. This was effectively achieved by showing that LY294002 does not impair mouse p53 serine 18 phosphorylation, under conditions where p53 stabilization is entirely disabled. Similarly, DNA-PK was ruled out as the relevant target of LY294002 through the use of cells deficient in DNA-PK activity. Thus, although not formally proven, it appears highly likely that the inhibitory effect of LY294002 on p53 activation, in the experimental models described in this study, is indeed due to direct inactivation of PI3K. This strongly suggests that activation of the PI3K pathway by serum-derived factors underlies the ability of such factors to facilitate p53 stabilization and activation by $\mathrm{CisPt}$, and perhaps also by other genotoxic agents.

Interestingly, the inhibition of p53 activation by LY294002 can occur at several distinct levels. In several cell types, the PI3K inhibitor prevented p53 stabilization, presumably by promoting its ongoing proteasomal degradation. In contrast, LY294002 had only a minor impact on p53 accumulation in 5FU-treated HCT116 cells, at least not when applied for only a few hours, yet it caused an attenuated transcriptional p53 response within this rather short time frame. Thus, in these cells, PI3K appears to play a role primarily in the biochemical potentiation of p53 as a transcription factor, rather than in modulation of its protein turnover rate. Several conditions where accumulation of p53 protein occurs without induction of its transcriptional activity have been reported, such as hypoxia $^{51}$ and inhibition of DNA synthesis. ${ }^{52}$ Interestingly, hypoxic conditions were shown to inhibit the activity of the PI3K pathway, in an experimental system similar to that where the effect of hypoxia on p53 was described. ${ }^{53,54}$ Thus, the molecular mechanisms underlying stabilization of the p53 protein overlap only partially with those controlling its activation as a transcriptional activator. In this regard, the precise roles of specific post-translational modifications or coactivators may be cell-type and cell-context dependent. For example, p300 is required for the activation of p53 as a transcription factor, but in some instances may also have a role either in its stabilization, presumably through acetylation of particular lysine residues that are otherwise targeted for ubiquitylation, or, alternatively, in its destabilization, through promoting Mdm2-mediated p53 polyubiquitylation. ${ }^{9}$ The interaction of p300 with p53 has been reported to be abrogated by hypoxia; ${ }^{.1}$ it will be interesting to test the effect of LY294002 upon this interaction.

The molecular mechanisms whereby PI3K presumably contributes to $p 53$ activation in the face of genotoxic stress remain to be elucidated. A large number of validated and candidate downstream targets of the PI3K pathway exist, ${ }^{55,56}$ precluding an exhaustive analysis of all possible effectors of PI3K as potential p53 modulators. Two of the major PI3K downstream effector pathways, AKT and mTOR, have been reported to regulate p53. ${ }^{31,32,57,58}$ However, in the experimental system employed in the present study, induction of p53 by DNA damage was found to be independent of AKT (Figure 2d), as well as mTOR (data not shown). Of note, levels of the p53 family member protein deltaNp63alpha have been shown to be dependent on PI3K activity, presumably through regulation of deltaNp63alpha mRNA levels. ${ }^{59}$ Whereas this p63 isoform can exert inhibitory effects on $\mathrm{p} 53,{ }^{60}$ the transcriptional activation-competent (TA) isoforms of p63 actually facilitate p53-dependent apoptosis. ${ }^{61}$ Although it is unlikely that effects of PI3K on p63 isoforms impinge on p53 protein levels, they could, in principle, play a role in the alterations in p53 transcriptional activity observed in HCT116 cells. However, any of the many other proteins whose expression or function are affected by PI3K signaling are equally likely to impact on p53 stability, through mechanisms that remain to be elucidated.

The relationship between PI3K activity and modulation of cell death is highly complex and context dependent. The AKT pathway, which is strongly and positively regulated by $\mathrm{PI} 3 \mathrm{~K}$, is a potent mediator of survival signals. ${ }^{12}$ Hence, it is to be expected that, under conditions where $\mathrm{PI} 3 \mathrm{~K}$ signals primarily through AKT, PI3K inactivation will actually enhance apoptosis rather than attenuate it. Indeed, inhibition of PI3K induces apoptosis in normal epithelial cells ${ }^{62}$ and in transformed epithelial cancer cell lines harboring amplified PIK3CA, the gene encoding the $\mathrm{p} 110$ alpha catalytic subunit of PI3K. ${ }^{14}$ Moreover, numerous studies have demonstrated that 
inhibition of PI3K activity by LY294002 sensitizes cancer cells to killing by genotoxic agents and other anticancer therapies. ${ }^{63,64}$ Yet, as shown here, PI3K inhibition can also exert antiapoptotic effects, and this is proposed to rely at least in part on a requirement for $\mathrm{PI}$ K signaling for optimal activation of p53 by several DNA-damaging agents. However, inhibition of PI3K will not necessarily be antiapoptotic in all circumstances where wt p53 activity is induced. Rather, we propose that the impact of PI3K inhibition on cell fate is likely to be determined by the balance between inhibition of PI3Kdependent prosurvival signals, and inhibition of p53-dependent proapoptotic signals. Indeed, in MCF7 cells, where AKT is constitutively active due to overexpression of HER2 and HER3 ${ }^{65}$ we observed that LY294002 treatment actually augments 5FU-induced apoptosis (data not shown), contrary to its effects in HCT116 cells. Presumably, the contribution of PI3K-dependent prosurvival signals is more significant in MCF7 than in HCT116 cells. Alternatively, the PI3K-mediated arm of the p53-dependent cell death pathway may be less prominent in MCF7 cells. PI3K blockage has been shown previously to protect hematopoietic cells from CisPt-induced apoptosis. ${ }^{66}$ In that case, protection was proposed to be due to reduced cell-cycle progression. However, we believe that this is not the case in the experimental systems described here. Thus, although LY294002 treatment without DNA damage did cause a mild reduction in the S-phase fraction of HCT116 cells, this reduction was very modest (from $21.4 \% \pm 2.9$ to $15.1 \% \pm 1.7$; data not shown), and occurred regardless of p53 status. Moreover, the p21 WAF1 protein, a key mediator of p53-dependent growth inhibition and a welldocumented attenuator of apoptosis, failed to protect HCT116 cells from 5FU-induced death. ${ }^{48}$ Furthermore, LY294002 actually reduced the extent of $\mathrm{p} 21$ induction by $5 \mathrm{FU}$ (Figure 4a). All these observations suggest that LY294002induced growth arrest is unlikely to be the major contributor to the antiapoptotic effect of this PI3K inhibitor, as described here. Rather, the protective mechanism is most likely to be due to the attenuation of p53 apoptotic activity under those circumstances. While this effect of LY294002 was evident in a number of different experimental settings, it is noteworthy that this is not always the case. For instance, in brain cells, LY294002 was actually shown to induce, rather than attenuate, p53 protein levels and activity. ${ }^{16}$ Hence, multiple factors probably determine the ultimate impact of $\mathrm{PI} 3 \mathrm{~K}$ inhibition on p53 function.

PI3K inhibition is expected to be useful as an adjuvant treatment for cancers with upregulation of the PI3K-AKT prosurvival pathway. ${ }^{12,16,17}$ Importantly, our results imply that, prior to the use of PI3K inhibitors in cancer clinical trials, possible antiapoptotic effects of such agents should be judiciously evaluated. The mutational and functional status of p53 in the targeted tumors is likely to be critical in this evaluation.

\section{Materials and Methods}

\section{Cells and treatments}

Primary MEFs were prepared from day 13.5 embryos of C57/BL mice according to standard protocols. ${ }^{67}$ p53-null MEFs were similarly prepared from C57/BL p53 knockout mice. ${ }^{5}$ Spontaneously immortalized ARF-null MEFs were from M Roussel and CJ. Sherr. SCID MEFs were from T Lapidot. MEFs were grown in DMEM (Gibco) with $5 \%$ heat-inactivated $(\mathrm{HI})$ FCS (Hyclone), supplemented with glutamine $(2 \mathrm{mM})$, beta mercaptoethanol ( $60 \mu \mathrm{M}$, Sigma), nonessential amino acids (Beit Haemek), pyruvate, and penicillin and streptomycin (Sigma). Dense and sparse cultures were plated as described before. ${ }^{18}$ HCT116 cells were obtained from B Vogelstein, and were grown in McCoy's medium (Sigma) containing 5\% HI FCS and penicillin and streptomycin. H5V cells were obtained from B Geiger, and were grown in DMEM with $5 \% \mathrm{HI} \mathrm{FCS} \mathrm{and}$ penicillin and streptomycin. Serum deprivation was carried out by rinsing adherent cells four times with DMEM over the course of half an hour, followed by incubation in DMEM. When appropriate, DMSO was added as control for chemicals dissolved in DMSO.

\section{Chemicals}

CisPt and 5FU were from ABIC (Israel), Camptothecin was from Sigma (Israel), Doxorubicin was from Pharmacia and Upjohn (Italy), MG132 was purchased from Calbiochem (San Diego, CA, USA), and SH-6 was from Alexis (CA, USA).

\section{Retroviral infection}

LZRSpBMN-IRES-EGFP, a retroviral plasmid encoding green fluorescent protein (GFP), was kindly provided by G Nolan. Infectious virus stocks were prepared and used as described. ${ }^{68}$

\section{Antibodies}

Monoclonal antibodies PAb421, PAb248, PAb1801, and DO-1 were a generous gift of $D$ Lane. Anti-mouse p53 CM5 polyclonal antibody was from Novocastra, UK. Anti Phospho-AKT/PKB (serine 473) was from Biosource, CA, USA. Anti-phospho-ERK was from Sigma (Israel), anti phospho-MAPKAPK-2 (threonine 334) was from Cell Signaling, antiphosphorylated-Serine 15 of human p53 was from New England Biolabs, anti-GFP was from Roche (Switzerland), and anti-GAPDH was from Research Diagnostics.

\section{Western immunoblotting}

Cell extracts were subjected to SDS-PAGE. Proteins were transferred to nitrocellulose membranes (Schleicher and Schuell, NH, USA) and probed with the indicated antibodies. Western blots were developed with the ECL reagent (Amersham Pharmacia, NJ, USA). In some experiments, expression of retrovirally transduced GFP was employed to monitor equal protein loading. To that end, cells were infected with a GFP retrovirus to yield a $5-10 \%$ infection rate, prior to plating for the experiment. At the end of the experiments, GFP was visualized by Western blotting with appropriate antibodies.

\section{RNA extraction and real-time quantitative RT-PCR}

Total RNA was isolated using the Nucleospin kit (Macherey-Nagel). Purified RNA was reverse transcribed with MMLV reverse transcriptase (Promega) and random hexamer mix. Primers for human p21, PUMA, and 18S mRNA were kindly provided by $V$ Rotter. Primers were designed using the Primers Express software (Applied Biosystems). Reverse primers were designed to hybridize to exon-exon junctions within the corresponding mRNA. The following primers were employed: p21: 
5' GGCAGACCAGCATGACAGATT, 3' GCGGATTAGGGCTTCCTCTT; PUMA: $5^{\prime}$ GCTGCTGTAGATACCGGAATGAA， $3^{\prime}$ AAAAAAATTAAC CAAACATGTACAGAAAAT; $18 \mathrm{~S}$ rRNA: $5^{\prime}$ CGCCGCTAGAGGT GAAATTCT, 3' CATTCTTGGCAAATGCTTTCG. For PCR analysis, appropriate amounts of cDNA (50 ng for PUMA and p21; $5 \mathrm{ng}$ for $18 \mathrm{~S}$ rRNA) were mixed with $10 \mu$ of real-time absolute PCR Mix (ABgene) and $0.5-0.65 \mathrm{nM}$ of each of the primers in a total volume of $20 \mu \mathrm{l}$. PCR programming was $10 \mathrm{~min}$ at $95^{\circ} \mathrm{C}$, followed by 40 cycles of $15 \mathrm{~s}$ at $95^{\circ} \mathrm{C}$, and $1 \mathrm{~min}$ at $60^{\circ} \mathrm{C}$. All samples were processed and measured at least in duplicate. The cycle threshold values of all samples were measured by the ABI Prism 7700 sequence detector system (Applied Biosystems) and were transformed to relative expression values using the standard curves measured in the same experiment.

\section{FACS analysis}

DNA content analysis by FACS was carried out as described before. ${ }^{69}$ Cells were analyzed by FACSORT (Becton Dickinson), using the CellQuest software.

For PI exclusion analysis, cells were washed twice with PBS, treated for 1 min with $0.05 \%$ trypsin-EDTA solution (Bet-Haemek, Israel), and rapidly washed again with PBS. Cells were dislodged from the dish by pipetting, centrifuged, and resuspended in PBS containing $1 \mu \mathrm{g} / \mathrm{ml} \mathrm{PI} \mathrm{(Sigma)} \mathrm{for}$ $30 \mathrm{~min}$, before being analyzed by FACSORT.

\section{Acknowledgements}

We thank Drs. M Roussel and CJ Sherr for the gift of ARF-null MEFs, Dr. D Lane for p53-specific antibodies, Dr. B Geiger for H5V cells, Dr. G Nolan for the LZRSpBMN-IRES-EGFP plasmid, Dr. Y Salomon for anti phosphoMAPKAPK-2 (threonine 334) antibodies, Dr. V Rotter for PCR primers, and Dr. B Vogelstein for HCT116 and HCT116 p53-/- cells. This work was supported in part by grant R37 CA40099 from the National Cancer Institute, a grant from the Center for Excellence Program of the Israel Science Foundation, grant QLK3-CT-2002-01956 from the European Commission, and the Yad Abraham Center for Cancer Diagnosis and Therapy.

\section{References}

1. Hollstein $M$, Hergenhahn $M$, Yang $Q$, Bartsch $H$, Wang $Z Q$ and Hainaut $P$ (1999) New approaches to understanding p53 gene tumor mutation spectra. Mutat. Res. 431: 199-209

2. Hussain SP, Hofseth LJ and Harris CC (2001) Tumor suppressor genes: at the crossroads of molecular carcinogenesis, molecular epidemiology and human risk assessment. Lung Cancer 34 (Suppl. 2): S7-15

3. Beroud C and Soussi T (2003) The UMD-p53 database: new mutations and analysis tools. Hum. Mutat. 21: 176-181

4. Donehower LA, Harvey M, Slagle BL, McArthur MJ, Montgomery Jr CA, Butel JS and Bradley A (1992) Mice deficient for p53 are developmentally normal but susceptible to spontaneous tumours. Nature 356: $215-221$

5. Jacks T, Remington L, Williams BO, Schmitt EM, Halachmi S, Bronson RT and Weinberg RA (1994) Tumor spectrum analysis in p53-mutant mice. Curr. Biol. 4: $1-7$

6. Malkin D, Li FP, Strong LC, Fraumeni Jr JF, Nelson CE, Kim DH, Kassel J, Gryka MA, Bischoff FZ, Tainsky MA and Friend SH (1990) Germ line p53 mutations in a familial syndrome of breast cancer, sarcomas, and other neoplasms. Science 250: 1233-1238

7. Srivastava S, Zou ZQ, Pirollo K, Blattner W and Chang EH (1990) Germ-line transmission of a mutated p53 gene in a cancer-prone family with Li-Fraumeni syndrome. Nature 348: 747-749
8. Vousden KH and Lu X (2002) Live or let die: the cell's response to p53. Nat. Rev. Cancer 2: 594-604

9. Michael $D$ and Oren M (2003) The p53-Mdm2 module and the ubiquitin system. Semin. Cancer Biol. 13: 49-58

10. El-Deiry WS (2003) The role of p53 in chemosensitivity and radiosensitivity. Oncogene 22: 7486-7495

11. Fridman JS and Lowe SW (2003) Control of apoptosis by p53. Oncogene 22: 9030-9040

12. Vivanco I and Sawyers CL (2002) The phosphatidylinositol 3-kinase AKT pathway in human cancer. Nat. Rev. Cancer 2: 489-501

13. Shayesteh L, Lu Y, Kuo WL, Baldocchi R, Godfrey T, Collins C, Pinkel D, Powell B, Mills GB and Gray JW (1999) PIK3CA is implicated as an oncogene in ovarian cancer. Nat. Genet. 21: 99-102

14. Singh B, Reddy PG, Goberdhan A, Walsh C, Dao S, Ngai I, Chou TC, O-Charoenrat P, Levine AJ, Rao PH and Stoffel A (2002) p53 regulates cell survival by inhibiting PIK3CA in squamous cell carcinomas. Genes Dev. 16: 984-993

15. Samuels Y, Wang Z, Bardelli A, Silliman N, Ptak J, Szabo S, Yan H, Gazdar A, Powell SM, Riggins GJ, Willson JK, Markowitz S, Kinzler KW, Vogelstein B and Velculescu VE (2004) High frequency of mutations of the PIK3CA gene in human cancers. Science 304: 554

16. Su JD, Mayo LD, Donner DB and Durden DL (2003) PTEN and phosphatidylinositol $3^{\prime}$-kinase inhibitors up-regulate p53 and block tumorinduced angiogenesis: evidence for an effect on the tumor and endothelial compartment. Cancer Res. 63: 3585-3592

17. Luo J, Manning BD and Cantley LC (2003) Targeting the PI3K-Akt pathway in human cancer: rationale and promise. Cancer Cell 4: 257-262

18. Bar J, Cohen-Noyman E, Geiger B and Oren M (2004) Attenuation of the p53 response to DNA damage by high cell density. Oncogene 2: 2

19. Dent $P$, Yacoub A, Fisher PB, Hagan MP and Grant $S$ (2003) MAPK pathways in radiation responses. Oncogene 22: 5885-5896

20. DeHaan RD, Yazlovitskaya EM and Persons DL (2001) Regulation of p53 target gene expression by cisplatin-induced extracellular signal-regulated kinase. Cancer Chemother. Pharmacol. 48: 383-388

21. Dudley DT, Pang L, Decker SJ, Bridges AJ and Saltiel AR (1995) A synthetic inhibitor of the mitogen-activated protein kinase cascade. Proc. Natl. Acad. Sci. USA 92: 7686-7689

22. Benhar M, Dalyot I, Engelberg D and Levitzki A (2001) Enhanced ROS production in oncogenically transformed cells potentiates c-Jun N-terminal kinase and p38 mitogen-activated protein kinase activation and sensitization to genotoxic stress. Mol. Cell. Biol. 21: 6913-6926

23. Bulavin DV, Saito S, Hollander MC, Sakaguchi K, Anderson CW, Appella E and Fornace Jr AJ (1999) Phosphorylation of human p53 by p38 kinase coordinates $\mathrm{N}$-terminal phosphorylation and apoptosis in response to UV radiation. EMBO J. 18: 6845-6854

24. Huang C, Ma WY, Maxiner A, Sun Y and Dong Z (1999) p38 kinase mediates UV-induced phosphorylation of p53 protein at serine 389 . J. Biol. Chem. 274 12229-12235

25. She QB, Chen $N$ and Dong $Z$ (2000) ERKs and p38 kinase phosphorylate p53 protein at serine 15 in response to UV radiation. J Biol Chem 275: 2044420449

26. Kishi $H$, Nakagawa $K$, Matsumoto $M$, Suga $M$, Ando M, Taya $Y$ and Yamaizumi M (2001) Osmotic shock induces G1 arrest through p53 phosphorylation at Ser33 by activated p38MAPK without phosphorylation at Ser15 and Ser20. J. Biol. Chem. 276: 39115-39122

27. Sanchez-Prieto R, Rojas JM, Taya Y and Gutkind JS (2000) A role for the p38 mitogen-acitvated protein kinase pathway in the transcriptional activation of p53 on genotoxic stress by chemotherapeutic agents. Cancer Res. 60: 2464-2472

28. Cuenda A, Rouse J, Doza YN, Meier R, Cohen P, Gallagher TF, Young PR and Lee JC (1995) SB 203580 is a specific inhibitor of a MAP kinase homologue which is stimulated by cellular stresses and interleukin-1. FEBS Lett. 364: 229233

29. Ben-Levy R, Leighton IA, Doza YN, Attwood P, Morrice N, Marshall CJ and Cohen P (1995) Identification of novel phosphorylation sites required for activation of MAPKAP kinase-2. EMBO J. 14: 5920-5930

30. Vlahos CJ, Matter WF, Hui KY and Brown RF (1994) A specific inhibitor of phosphatidylinositol 3-kinase, 2-(4-morpholinyl)-8-phenyl-4H-1-benzopyran-4one (LY294002). J. Biol. Chem. 269: 5241-5248 
31. Mayo LD and Donner DB (2001) A phosphatidylinositol 3-kinase/Akt pathway promotes translocation of Mdm2 from the cytoplasm to the nucleus. Proc. Natl. Acad. Sci. USA 98: 11598-11603

32. Zhou BP, Liao Y, Xia W, Zou Y, Spohn B and Hung MC (2001) HER-2/neu induces p53 ubiquitination via Akt-mediated MDM2 phosphorylation. Nat. Cell Biol. 3: $973-982$

33. Mitsuuchi $Y$, Johnson SW, Selvakumaran M, Williams SJ, Hamilton TC and Testa JR (2000) The phosphatidylinositol 3-kinase/AKT signal transduction pathway plays a critical role in the expression of p21WAF1/CIP1/SDI1 induced by cisplatin and paclitaxel. Cancer Res. 60: 5390-5394

34. Murray SA, Zheng H, Gu L and Jim Xiao ZX (2003) IGF-1 activates p21 to inhibit UV-induced cell death. Oncogene 22: 1703-1711

35. Kozikowski AP, Sun H, Brognard J and Dennis PA (2003) Novel PI analogues selectively block activation of the pro-survival serine/threonine kinase Akt. J. Am. Chem. Soc. 125: 1144-1145

36. Hall-Jackson CA, Cross DA, Morrice N and Smythe C (1999) ATR is a caffeinesensitive, DNA-activated protein kinase with a substrate specificity distinct from DNA-PK. Oncogene 18: 6707-6713

37. Hammond EM, Denko NC, Dorie MJ, Abraham RT and Giaccia AJ (2002) Hypoxia links ATR and p53 through replication arrest. Mol. Cell. Biol. 22: 18341843

38. Goodarzi AA and Lees-Miller SP (2004) Biochemical characterization of the ataxia-telangiectasia mutated (ATM) protein from human cells. DNA Repair (Amst) 3: 753-767

39. Stiff T, O'Driscoll M, Rief N, Iwabuchi K, Lobrich M and Jeggo PA (2004) ATM and DNA-PK function redundantly to phosphorylate H2AX after exposure to ionizing radiation. Cancer Res. 64: 2390-2396

40. Banin S, Moyal L, Shieh S, Taya Y, Anderson CW, Chessa L, Smorodinsky NI, Prives C, Reiss Y, Shiloh Y and Ziv Y (1998) Enhanced phosphorylation of p53 by ATM in response to DNA damage. Science 281: 1674-1677

41. Khanna KK and Jackson SP (2001) DNA double-strand breaks: signaling, repair and the cancer connection. Nat. Genet. 27: 247-254

42. Siliciano JD, Canman CE, Taya Y, Sakaquchi K, Appella E and Kastan MB (1997) DNA damage induces phosphorylation of the amino terminus of p53. Genes Dev, 11: 3471-3481

43. Damia G, Filiberti L, Vikhanskaya F, Carrassa L, Taya $Y$, D'Incalci M and Broggini M (2001) Cisplatinum and taxol induce different patterns of p53 phosphorylation. Neoplasia 3: 10-16

44. Blunt T, Finnie NJ, Taccioli GE, Smith GC, Demengeot J, Gottlieb TM, Mizuta R, Varghese AJ, Alt FW, Jeggo PA and Jackson SP (1995) Defective DNA dependent protein kinase activity is linked to $V(D) J$ recombination and DNA repair defects associated with the murine scid mutation. Cell 80: 813-823

45. Nakano K and Vousden KH (2001) PUMA, a novel proapoptotic gene, is induced by p53. Mol. Cell 7: 683-694

46. Yu J, Zhang L, Hwang PM, Kinzler KW and Vogelstein B (2001) PUMA induces the rapid apoptosis of colorectal cancer cells. Mol. Cell 7: 673-682

47. Jeffers JR, Parganas E, Lee Y, Yang C, Wang J, Brennan J, MacLean KH, Han J, Chittenden T, Ihle JN, McKinnon PJ, Cleveland JL and Zambetti GP (2003) Puma is an essential mediator of p53-dependent and -independent apoptotic pathways. Cancer Cell 4: 321-328

48. Bunz F, Hwang PM, Torrance C, Waldman T, Zhang Y, Dillehay L, Williams J, Lengauer C, Kinzler KW and Vogelstein B (1999) Disruption of p53 in human cancer cells alters the responses to therapeutic agents. J. Clin. Invest. 104: 263-269

49. Vogelstein B, Lane D and Levine AJ (2000) Surfing the p53 network. Nature 408: $307-310$

50. Oren M (2003) Decision making by p53: life, death and cancer. Cell Death Differ. 10: 431-442

51. Koumenis $C$, Alarcon R, Hammond E, Sutphin P, Hoffman W, Murphy M, Derr J, Taya Y, Lowe SW, Kastan M and Giaccia A (2001) Regulation of p53 by hypoxia: dissociation of transcriptional repression and apoptosis from p53 dependent transactivation. Mol. Cell. Biol. 21: 1297-1310

52. Gottifredi V, Shieh S, Taya $Y$ and Prives $C$ (2001) p53 accumulates but is functionally impaired when DNA synthesis is blocked. Proc. Natl. Acad. Sci. USA 98: 1036-1041
53. Hirai K, Hayashi T, Chan PH, Zeng J, Yang GY, Basus VJ, James TL and Litt L (2004) PI3K inhibition in neonatal rat brain slices during and after hypoxia reduces phospho-Akt and increases cytosolic cytochrome $\mathrm{C}$ and apoptosis. Brain Res. Mol. Brain Res. 124: 51-61

54. Schnitzer SE, Schmid T, Zhou J, Eisenbrand G and Brune B (2005) Inhibition of GSK3beta by indirubins restores HIF-1alpha accumulation under prolonged periods of hypoxia/anoxia. FEBS Lett. 579: 529-533

55. Isakoff SJ, Cardozo T, Andreev J, Li Z, Ferguson KM, Abagyan R, Lemmon MA, Aronheim A and Skolnik EY (1998) Identification and analysis of PH domain-containing targets of phosphatidylinositol 3-kinase using a novel in vivo assay in yeast. EMBO J. 17: 5374-5387

56. Krugmann S, Anderson KE, Ridley SH, Risso N, McGregor A, Coadwell J, Davidson K, Eguinoa A, Ellson CD, Lipp P, Manifava M, Ktistakis N, Painter G, Thuring JW, Cooper MA, Lim ZY, Holmes AB, Dove SK, Michell RH, Grewal A, Nazarian A, Erdjument-Bromage $H$, Tempst $P$, Stephens LR and Hawkins PT (2002) Identification of ARAP3, a novel PI3K effector regulating both Arf and Rho GTPases, by selective capture on phosphoinositide affinity matrices. Mol. Cell 9: 95-108

57. Castedo M, Ferri KF, Blanco J, Roumier T, Larochette N, Barretina J, Amendola A, Nardacci R, Metivier D, Este JA, Piacentini M and Kroemer G (2001) Human immunodeficiency virus 1 envelope glycoprotein complexinduced apoptosis involves mammalian target of rapamycin/FKBP12rapamycin-associated protein-mediated p53 phosphorylation. J. Exp. Med. 194: 1097-1110

58. Castedo M, Roumier T, Blanco J, Ferri KF, Barretina J, Tintignac LA, Andreau K, Perfettini JL, Amendola A, Nardacci R, Leduc P, Ingber DE, Druillennec S, Roques B, Leibovitch SA, Vilella-Bach M, Chen J, Este JA, Modjtahedi N, Piacentini M and Kroemer G (2002) Sequential involvement of Cdk1, mTOR and p53 in apoptosis induced by the HIV-1 envelope. EMBO J. 21: 4070-4080

59. Barbieri CE, Barton CE and Pietenpol JA (2003) Delta Np63 alpha expression is regulated by the phosphoinositide 3-kinase pathway. J. Biol. Chem. 278: 51408-51414. Epub 52003 Oct 51410.

60. Yang A, Kaghad M, Wang Y, Gillett E, Fleming MD, Dotsch V, Andrews NC, Caput $D$ and McKeon $F$ (1998) p63, a p53 homolog at 3q27-29, encodes multiple products with transactivating, death-inducing, and dominant-negative activities. Mol. Cell 2: 305-316

61. Flores ER, Tsai KY, Crowley D, Sengupta S, Yang A, McKeon F and Jacks T (2002) p63 and p73 are required for p53-dependent apoptosis in response to DNA damage. Nature 416: 560-564

62. Khwaja A, Rodriguez-Viciana P, Wennstrom S, Warne PH and Downward J (1997) Matrix adhesion and Ras transformation both activate a phosphoinositide $3-\mathrm{OH}$ kinase and protein kinase B/Akt cellular survival pathway. EMBO J. 16: 2783-2793

63. Collis SJ, Swartz MJ, Nelson WG and DeWeese TL (2003) Enhanced radiation and chemotherapy-mediated cell killing of human cancer cells by small inhibitory RNA silencing of DNA repair factors. Cancer Res. 63: 1550-1554

64. Yu C, Rahmani M, Dai Y, Conrad D, Krystal G, Dent P and Grant S (2003) The lethal effects of pharmacological cyclin-dependent kinase inhibitors in human leukemia cells proceed through a phosphatidylinositol 3-kinase/Akt-dependent process. Cancer Res. 63: 1822-1833

65. Knuefermann C, Lu Y, Liu B, Jin W, Liang K, Wu L, Schmidt M, Mills GB, Mendelsohn J and Fan Z (2003) HER2/PI-3K/Akt activation leads to a multidrug resistance in human breast adenocarcinoma cells. Oncogene 22: 3205-3212

66. Nimbalkar D, Henry MK and Quelle FW (2003) Cytokine activation of phosphoinositide 3-kinase sensitizes hematopoietic cells to cisplatin-induced death. Cancer Res. 63: 1034-1039

67. Zindy F, Quelle DE, Roussel MF and Sherr CJ (1997) Expression of the p16INK4a tumor suppressor versus other INK4 family members during mouse development and aging. Oncogene 15: 203-211

68. Gottlieb E and Oren M (1998) p53 facilitates pRb cleavage in IL-3-deprived cells: novel pro-apoptotic activity of p53. EMBO J. 17: 3587-3596

69. Haupt Y, Rowan S and Oren M (1995) p53-mediated apoptosis in HeLa cells can be overcome by excess pRB. Oncogene 10: 1563-1571 